\title{
Rheic Ocean ophiolitic remnants in southern Iberia questioned by SHRIMP U-Pb zircon ages on the Beja-Acebuches amphibolites
}

\author{
A. Azor, ${ }^{1}$ D. Rubatto, ${ }^{2}$ J. F. Simancas, ${ }^{1}$ F. González Lodeiro, ${ }^{1}$ D. Martínez Poyatos, \\ L. M. Martín Parra, ${ }^{3}$ and J. Matas ${ }^{3}$ \\ Received 10 April 2008; revised 17 June 2008; accepted 15 July 2008; published 4 October 2008.
}

[1] The Rheic Ocean was a major oceanic domain between Avalonia and Gondwana in Ordovician-Silurian times. Most of the Paleozoic plate reconstructions assume that the Rheic Ocean suture lies within southern Iberia, coinciding with the contact between the South Portuguese Zone and the Ossa-Morena Zone. This paper reports four Sensitive High Resolution Ion Micro-Probe (SHRIMP) U-Pb zircon ages from midocean ridge basalt (MORB)-featured rocks of the BejaAcebuches Amphibolite unit, which crops out along the boundary between the Ossa-Morena and the South Portuguese Zone, and is considered its most conspicuous suture unit. The obtained ages range from $332 \pm 3$ to $340 \pm 4 \mathrm{Ma}$, corresponding to the crystallization of the mafic protoliths. These Early Carboniferous ages for the Beja-Acebuches amphibolites imply that this unit can no longer be viewed as an ophiolite belonging to the Rheic Ocean suture, since this oceanic domain was presumably closed in Devonian times. Tectonic reconstructions joining in a single suture line the Beja-Acebuches Amphibolite unit in southern Iberia to either the Devonian Lizard ophiolite in southern England or the root zone of the Devonian/ Ordovician ophiolitic units in northwest Iberia must be therefore reconsidered because of the age difference. We interpret the Beja-Acebuches Amphibolite unit to represent a narrow and very ephemeral realm of oceanic-like crust that opened in Early Carboniferous times, after total consumption of the Rheic Ocean. We suggest that a mantle plume underneath southern Iberia in Early Carboniferous times is the most plausible large-scale geodynamic scenario for the formation of these MORB-featured rocks. Citation: Azor, A., D. Rubatto, J. F. Simancas, F. González Lodeiro, D. Martínez Poyatos, L. M. Martín Parra, and J. Matas (2008), Rheic Ocean ophiolitic remnants in southern Iberia questioned by SHRIMP

\footnotetext{
${ }^{1}$ Departamento de Geodinámica, Universidad de Granada, Granada, Spain.

${ }^{2}$ Research School of Earth Sciences, The Australian National University, Canberra, ACT, Australia.

${ }^{3}$ Instituto Geológico y Minero de España, Madrid, Spain.

Copyright 2008 by the American Geophysical Union. 0278-7407/08/2008TC002306
}

$\mathrm{U}-\mathrm{Pb}$ zircon ages on the Beja-Acebuches amphibolites, Tectonics, 27, TC5006, doi:10.1029/2008TC002306.

\section{Introduction}

[2] Remnants of oceanic lithosphere, namely, ophiolites, obducted and welded in between continental lithosphere during collision can be preserved within mountain belts, marking preexisting oceanic domains as suture zones. Thus, identification and characterization of ophiolitic units is one of the main targets of studies focused on the tectonic evolution of orogens. In fact, plate tectonic reconstructions, particularly for pre-Mesozoic times, are primarily based on the suture lines recognizable within mountain belts. Nevertheless, recognizing suture zones in orogens is not a simple task, because ophiolites may be missing or may be highly dismembered. This makes it difficult to distinguish different oceanic realms, from true oceans to ephemeral basins. The Late Paleozoic Variscan-Alleghanian Orogen (Figure 1a) is an example of region where the origin of ophiolitic remnants remains unclear, thus emphasizing the need for multisource data (paleomagnetic, paleontological/stratigraphical, structural/ tectonometamorphic and geochronological/geophysical) to evaluate conflicting paleogeographic models.

[3] There are substantial controversies and uncertainties concerning the timing, location, extent and continuity of oceanic domains sutured along the vast Variscan-Alleghanian Orogen [e.g., Tait et al., 2000; Matte, 2001; Nyscether et al., 2002; Linnemann et al., 2004]. This orogen appears as dispersed outcrops in western Europe, northwest Africa and northeast America (Figure 1a). Despite uncertainties regarding its evolution, some general aspects of the kinematics of continental blocks from Early to Late Paleozoic times leading to the Variscan-Alleghanian orogeny are well established. In a simplistic way, the Carboniferous VariscanAlleghanian collision was preceded by the following plate dispersal and accretion episodes [e.g., Matte, 2001]: (1) Cambrian to Ordovician rifting along the northern Gondwana margin formed Avalonia as a separate microplate and a number of peri-Gondwana terranes [Cocks and Torsvik, 2006], usually grouped under the term Armorica microplate; (2) Rheic Ocean formation in Ordovician-Silurian times between the drifting Avalonia and Armorica (Figure 1b); and (3) consumption of the Rheic Ocean in Devonian time and initial collision of Gondwana, Gondwana-related terranes (Armorica) and Avalonia in Devonian-Early Carboniferous times.

[4] Most of the paleotectonic reconstructions available assume the Rheic Ocean suture to crop out in southern 


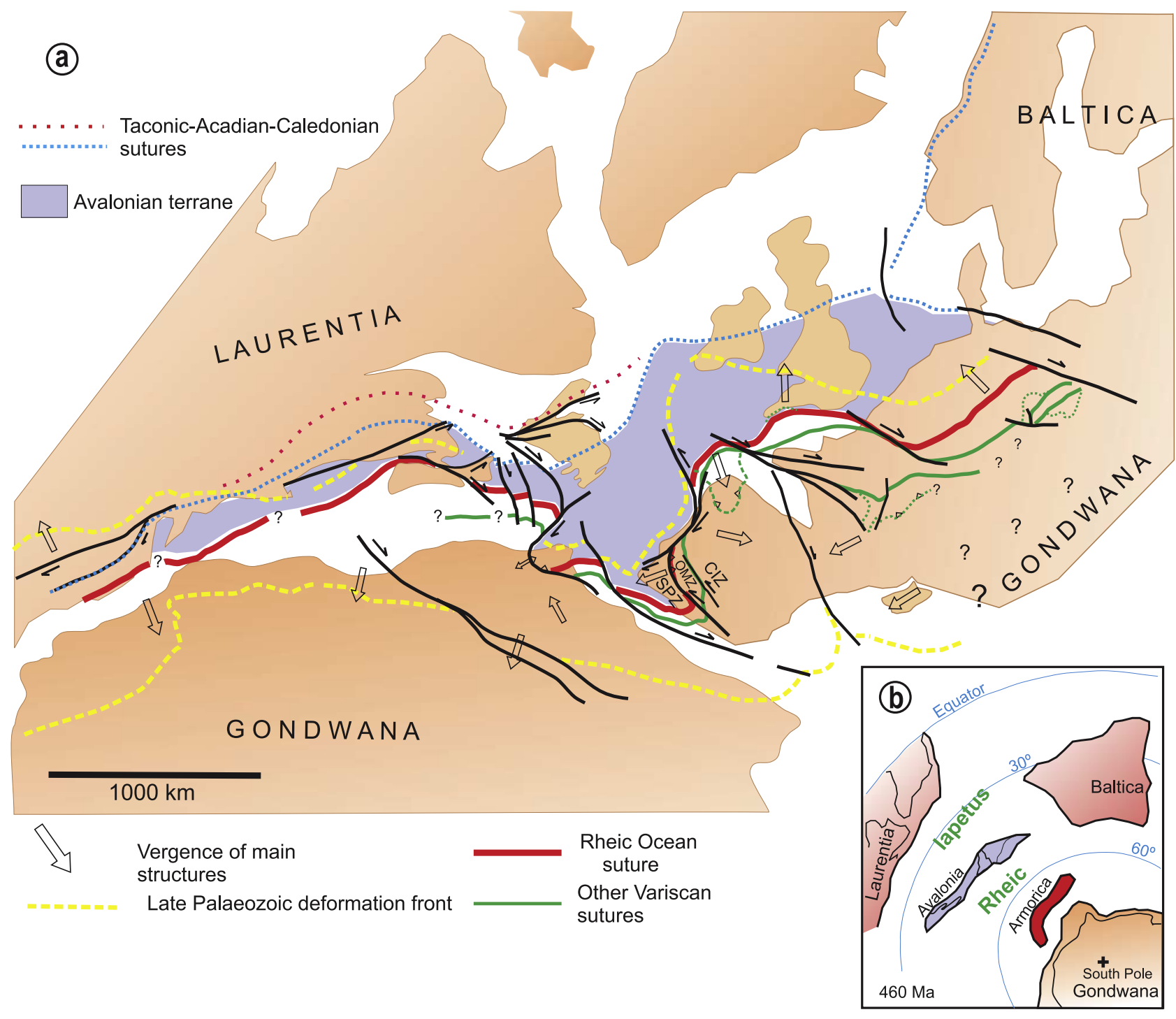

Figure 1. (a) Late Carboniferous reconstruction of the Variscan-Alleghanian Orogenic Belt (slightly modified from Simancas et al. [2005, and references therein]). The inferred positions of the Rheic Ocean suture and other Variscan second-order sutures have been depicted. CIZ, Central Iberian Zone; OMZ, Ossa-Morena Zone; SPZ, South Portuguese Zone. (b) Middle Ordovician paleogeographic reconstruction of Gondwana, Gondwana-related terranes (Armorica), Avalonia, Baltica, and Laurentia with the oceanic domains open in between (slightly modified from Nyscether et al. [2002]).

Iberia, coinciding with the contact between the South Portuguese Zone (SPZ) and the Ossa-Morena Zone (OMZ) [e.g., Matte, 2001] (Figures 1a and 2). This paper aims to refine the meaning and time correlation of Variscan suture contacts in southern Iberia. We present the first U-Pb ion microprobe ages on zircons from mafic rocks generally attributed to the Rheic Ocean suture. Our results point to a new interpretation for these rocks, which questions essential aspects of the paleotectonic reconstructions available.

\section{Geological Setting}

[5] The Iberian Massif (Figure 2a) in western Europe constitutes the largest and by far the most representative outcrop in the Variscan Orogen, with several suture-related units, some of them containing rocks with oceanic affinity [e.g., Martínez Catalán et al., 1997; Matte, 2001; Araújo et al., 2005; Simancas et al., 2005; Pin et al., 2006]. Variscan Iberia has been classically divided into two transects: (1) a northern one consisting of an east vergent orogenic wedge developed on the paleopassive margin of Gondwana, which is overthrust to the west by a pile of allocthonous tectonic units, some of them with high-pressure metamorphism and/ or ophiolitic rocks [e.g., Pérez-Estaún et al., 1991; Arenas et al., 2007a]; and (2) a southern one with a predominant southwest vergence [e.g., Simancas et al., 2001], which includes three continental blocks (SPZ, OMZ, and Central 


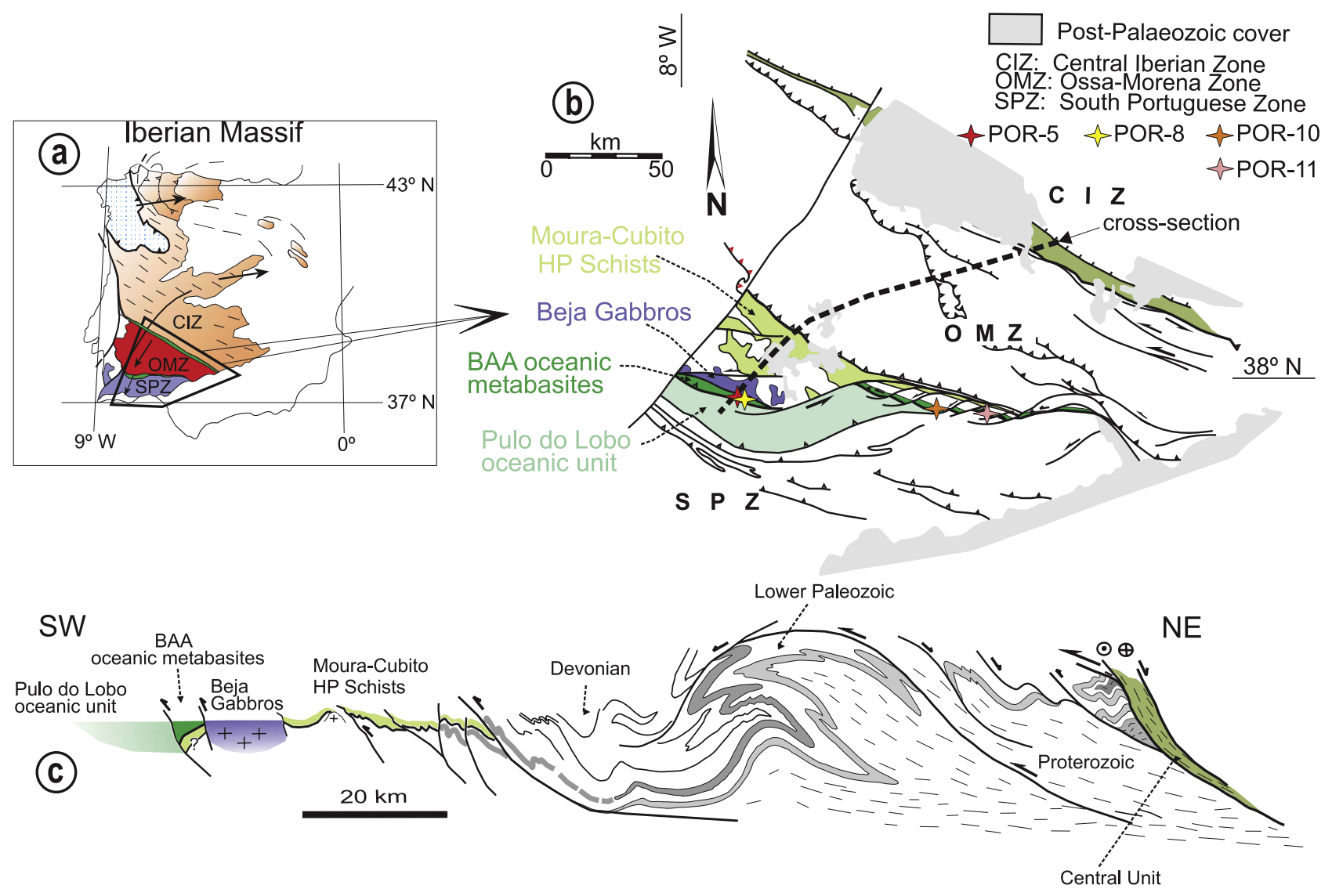

Figure 2. (a) Variscan tectonic zones in the Iberian Massif with location of putative suture-related units in southern Iberia (green). The blue dotted pattern corresponds to the NW Iberia allochthonous tectonic units containing ophiolitic rocks. The zones in the Iberian Massif have been marked with the same colors as in Figure $1 \mathrm{~b}$ according to their attribution to Gondwana, Armorica, and Avalonia. CIZ, Central Iberian Zone; OMZ, Ossa-Morena Zone; SPZ, South Portuguese Zone. (b) Geological sketch of southern Iberia, where the different units shaping the boundary between the Ossa-Morena and South Portuguese zones have been depicted. The samples studied are located by stars. (c) Schematic cross section of southern Iberia (see location in Figure 2b). The southern part of the cross section is based on work by Fonseca and Ribeiro [1993] and Araújo et al. [2005].

Iberian Zone (CIZ)) with inferred suture contacts in between (Figure 2).

[6] The OMZ/CIZ boundary is marked by a complex tectonic unit, namely, the Badajoz-Córdoba Shear Zone or Central Unit (Figure 2) [Burg et al., 1981; Azor et al., 1994]. This unit includes metasediments, orthogneisses, and amphibolites with scarce eclogite relics [Abalos et al., 1991; López Sánchez-Vizcaino et al., 2003]. This boundary has been interpreted either as a suture of the Late Paleozoic Variscan Orogen, where at least some of the allochthonous ophiolitic units of NW Iberia would be rooted [e.g., Matte, 2001; Simancas et al., 2005; Pin et al., 2006], or as a suture of the Late Precambrian Cadomian Orogen, later reactivated as an intracontinental left-lateral shear zone during the Variscan Orogeny [e.g., Abalos et al., 1991; Quesada, 1991]. The radiometric ages available point, however, to a Lower Paleozoic age for some amphibolite protoliths and an Early Carboniferous age for the high-grade metamorphism [Ordóñez-Casado, 1998], thus favoring the interpretation of this boundary as a Variscan suture. Some of the amphibolites (the Early Paleozoic ones) feature an oceanic geochemical signature [Ordónez-Casado, 1998; Gómez-Pugnaire et al., 2003], thus supporting the interpretation of existence along this boundary of very dismembered ophiolitic rocks, representing some sort of oceanic domain (Figures 1 and 2) that was closed during the Variscan Orogeny. Paleontological/faunistic data [Robardet, 2003] argue against the existence of a wide ocean between the CIZ and the OMZ at Ordovician to Devonian times. Therefore, this suture would represent most probably the relics of a relatively narrow oceanic realm developed during the Lower Paleozoic between Gondwana (CIZ) and Armorica (OMZ) (Figure 1b).

[7] The most compelling evidence for interpreting the OMZ/SPZ contact as the Rheic Ocean suture (Figure 1) has been the existence of a continuous band of amphibolites with oceanic affinity, namely, the Beja-Acebuches Amphibolite (BAA) unit (Figure 2) [Bard, 1977; Bard and Moine, 
1979; Fonseca and Ribeiro, 1993; Quesada et al., 1994; Castro et al., 1996]. Additionally, south of the BAA unit, metasedimentary rocks with some metabasalt intercalations of normal mid-ocean ridge basalt (NMORB) oceanic signature (the Pulo do Lobo Unit; Figures $2 \mathrm{~b}$ and $2 \mathrm{c}$ ) have been interpreted as an accretionary prism related to a north dipping subduction zone [Eden and Andrews, 1990]. Finally, north of the BAA unit, the Moura-Cubito Schists (Figures $2 \mathrm{~b}$ and $2 \mathrm{c}$ ) intercalate slices of basic rocks, partly with oceanic affinity. These schists show high-pressure/lowtemperature metamorphism [Booth-Rea et al., 2006] with eclogite facies relics in some of the amphibolite intercalations [Fonseca et al., 1999]. Accordingly, the Moura-Cubito Schists have been interpreted as an obducted accretionary complex rooted to the south in the suture zone [Araújo et al., 2005].

\section{Beja-Acebuches Amphibolites and Beja Gabbros}

[8] We report here new geochronological data from the BAA unit, which has been interpreted by some authors as a dismembered ophiolite [Fonseca and Ribeiro, 1993; Quesada et al., 1994]. The BAA unit crops out for $200 \mathrm{~km}$ along of the OMZ/SPZ boundary (Figure $2 \mathrm{~b}$ ) with a thickness of 500-2000 m. To the east, in the Spanish sector, the BAA unit is made up of medium- and fine-grained amphibolites, likely derived from gabbros and maybe some basalts, with medium-grained ones dominating toward the structural top (north) and fine-grained ones becoming dominant toward the structural bottom (south) [Quesada et al., 1994]. To the west in the Portuguese sector, a sequence including serpentinites, dunites, amphibolites/gabbros and basalts has been reconstructed from scattered outcrops [Fonseca and Ribeiro, 1993].

[9] Geochemical data from the BAA are abundant, though their interpretation is far from being straightforward. Bard [1977] proposed that the BAA unit may represent either the very early stages of development of a marginal volcanic arc or a very ephemeral and narrow oceanic basin (intracontinental rifting). Quesada et al. [1994] interpreted the BAA unit as representing an oceanic lithosphere formed within an intra-arc or back-arc marginal basin. Castro et al. [1996] envisaged a mid-ocean ridge setting as the most probable for the generation of the BAA unit. Finally, Pin et al. [1999] shown that metagabbros and metabasalts from the BAA unit have very different $\varepsilon_{\mathrm{Nd}}$ values, thus concluding that the gabbroic and basaltic rocks may not be cogenetic; they also pointed out that only some of the metabasalts display $\varepsilon_{\mathrm{Nd}}$ values similar to NMORBs, with most of them showing significant interaction with continental components.

[10] The main deformational fabric in the BAA unit indicates oblique left-lateral top-to-the-SW ductile shearing [Crespo-Blanc and Orozco, 1991] occurred at mainly lowpressure amphibolite to greenschist facies conditions [Bard and Moine, 1979; Castro et al., 1996]. Some authors [e.g., Fonseca and Ribeiro, 1993] recognize an early hightemperature low-pressure (granulite facies?) north directed ductile shearing, which is interpreted as related to ophiolite obduction. Metamorphic ages in the BAA unit were obtained by Dallmeyer et al. [1993] and Castro et al. [1999] using the ${ }^{40} \mathrm{Ar} /{ }^{39} \mathrm{Ar}$ method on amphibole concentrates; these ages, which are thought to constrain cooling below $500^{\circ} \mathrm{C}$, range from 328 to $346 \mathrm{Ma}$.

[11] In Portugal, the BAA unit is bounded to the north by the undeformed Beja Gabbros (Figures $2 \mathrm{~b}$ and 2c). Conventional $\mathrm{U}-\mathrm{Pb}$ zircon dating of these gabbros yielded an age of $\approx 350-352$ Ma [Pin et al., 1999], while Sensitive High Resolution Ion Micro-Probe (SHRIMP) U-Pb on zircons has provided an age of $342 \mathrm{Ma}$ [Jesus et al., 2007]. These ages are consistent with those previously obtained by ${ }^{40} \mathrm{Ar} /{ }^{39} \mathrm{Ar}$ on amphibole concentrates from the gabbros ( $\approx 339 \mathrm{Ma}$ [Dallmeyer et al., 1993]). Unfortunately, the relationships between the Beja Gabbros and the BAA unit cannot be discerned in the field, since they are separated by faults. Thus, in the Beja Gabbros the lack of the tectonic fabric that pervades the BAA rocks has been taken as evidence for a pre-Carboniferous age of the BAA unit.

\section{Sample Description and U-Pb Ages}

[12] We report the first protolith ages on the BAA unit. We collected 20 samples, selecting the ones containing zircons for the geochronological study. Three of the zirconbearing samples are coarse-grained metabasites (POR-5, POR-8, and POR-10), while the fourth is a fine-grained metabasite (POR-11) (Figure 2b).

[13] Sample POR-5 is a medium-grained light colored gabbro with a nearly isotropic fabric. It contains plagioclase, clinopyroxene, ore minerals, accessory zircon and rare secondary chlorite. Zircon crystals are transparent, pink, clear, and appear as rounded fragments of larger grains. In cathodoluminescence (CL), most crystals display a broad banded oscillatory zoning pattern with an irregular, small (10-40 $\mu \mathrm{m}$ across) and CL-bright rim in a few crystals. The zoned zircons have medium to low $\mathrm{U}$ and $\mathrm{Th}$ contents $(\mathrm{Th} / \mathrm{U}$ $0.3-0.4$ ) and yield a concordia age of $340 \pm 4 \mathrm{Ma}$ (Figure 2 and Table 1), which is interpreted as dating the intrusion of the gabbroic protolith. Three other analyses, one of them on a bright rim, yielded apparent younger ages down to $219 \mathrm{Ma}$, which are suspected of $\mathrm{Pb}$ loss, possibly related to metamorphism. This sample also contains a few smaller $(<100 \mu \mathrm{m})$ zircon grains $(5 \%$ of the total) with euhedral faces and a complex oscillatory zoning. One of these grains yielded an age of $533 \pm 7$ Ma (Figure 3 and Table 1), suggesting a xenocrystic or inherited origin.

[14] Sample POR-8 is a medium-grained dark colored amphibolite with a planar fabric related to tectonic deformation. It contains plagioclase, amphibole, ore minerals, accessory zircon and secondary chlorite. The zircons recovered from this sample have external features, internal zoning and U-Th composition similar to the main zircon population in sample POR-5. The zircons yielded a concordia age of $337 \pm 5$ Ma (Figure 3 and Table 1).

[15] Sample POR-10 is a strongly foliated mediumgrained amphibolite consisting of plagioclase, amphibole, 
Table 1. SHRIMP U-Pb-Th Analyses

\begin{tabular}{|c|c|c|c|c|c|c|c|c|c|c|c|}
\hline Spot & $\begin{array}{c}{ }^{206} \mathrm{~Pb} \\
(\%)\end{array}$ & $\underset{(\mathrm{ppm})}{\mathrm{U}}$ & $\begin{array}{c}\text { Th } \\
\text { (ppm) }\end{array}$ & $\mathrm{Th} / \mathrm{U}$ & ${ }^{207} \mathrm{~Pb} /{ }^{235} \mathrm{U}$ & $\begin{array}{c}\text { Error } \\
(\%)\end{array}$ & ${ }^{206} \mathrm{~Pb} /{ }^{238} \mathrm{U}$ & $\begin{array}{c}\text { Error } \\
(\%)\end{array}$ & $\begin{array}{c}\text { Error } \\
\text { Correlation }\end{array}$ & $\begin{array}{c}{ }^{206} \mathrm{~Pb} /{ }^{238} \mathrm{U} \\
\mathrm{Age}\end{array}$ & $\pm 1 \sigma$ \\
\hline POR5-1.1 ${ }^{\mathrm{a}}$ & 0.35 & 134 & 42 & 0.31 & 0.3229 & 7.67 & 0.04939 & 1.50 & 0.195 & 310.8 & 4.5 \\
\hline POR5-4.1 ${ }^{\mathrm{a}}$ & 0.49 & 111 & 34 & 0.31 & 0.3151 & 8.75 & 0.05167 & 1.50 & 0.172 & 324.8 & 4.8 \\
\hline POR5-5.1 ${ }^{\mathrm{a}}$ & 0.35 & 225 & 96 & 0.43 & 0.3702 & 2.73 & 0.05201 & 1.36 & 0.500 & 326.8 & 4.3 \\
\hline POR5-10.1 & 0.22 & 88 & 24 & 0.28 & 0.3348 & 7.58 & 0.05328 & 1.52 & 0.201 & 334.7 & 5.0 \\
\hline POR5-2.1 & 0.51 & 266 & 118 & 0.44 & 0.3642 & 4.10 & 0.05332 & 1.36 & 0.333 & 334.8 & 4.5 \\
\hline POR5-2.2 & 0.40 & 104 & 31 & 0.29 & 0.4334 & 2.88 & 0.05335 & 2.20 & 0.764 & 335.1 & 7.2 \\
\hline POR5-6.2 & 0.24 & 139 & 44 & 0.31 & 0.3418 & 7.34 & 0.05335 & 1.45 & 0.198 & 335.1 & 4.7 \\
\hline POR5-7.1 & 0.32 & 197 & 87 & 0.44 & 0.4043 & 1.96 & 0.05387 & 1.38 & 0.702 & 338.2 & 4.5 \\
\hline POR5-3.1 & 0.13 & 242 & 99 & 0.41 & 0.3869 & 2.46 & 0.05419 & 1.36 & 0.551 & 340.2 & 4.5 \\
\hline POR5-13.1 & 0.40 & 123 & 44 & 0.36 & 0.3432 & 6.62 & 0.05460 & 1.46 & 0.220 & 342.7 & 4.9 \\
\hline POR5-11.1 & 0.14 & 452 & 117 & 0.26 & 0.4149 & 1.60 & 0.05482 & 1.33 & 0.830 & 344.1 & 4.5 \\
\hline POR5-8.1 & 0.01 & 263 & 76 & 0.29 & 0.3760 & 3.59 & 0.05496 & 1.36 & 0.380 & 344.9 & 4.6 \\
\hline POR5-9.1 & 0.39 & 114 & 37 & 0.32 & 0.3350 & 6.17 & 0.05514 & 1.46 & 0.237 & 346.0 & 4.9 \\
\hline POR5-12.1 $\mathrm{inh}^{\mathrm{b}}$ & 0.16 & 764 & 185 & 0.24 & 0.6795 & 1.59 & 0.08622 & 1.36 & 0.851 & 533.1 & 6.9 \\
\hline POR8-8 & 0.76 & 122 & 33 & 0.27 & 0.3509 & 5.93 & 0.05235 & 1.71 & 0.288 & 328.9 & 5.5 \\
\hline POR8-6 & 0.34 & 268 & 81 & 0.30 & 0.3720 & 3.14 & 0.05290 & 1.53 & 0.488 & 332.3 & 5.0 \\
\hline POR8-4 & 0.11 & 249 & 89 & 0.36 & 0.3851 & 2.56 & 0.05374 & 1.54 & 0.601 & 337.4 & 5.1 \\
\hline POR8-11 & 0.47 & 261 & 63 & 0.24 & 0.3603 & 3.80 & 0.05376 & 1.72 & 0.453 & 337.6 & 5.7 \\
\hline POR8-9 & 0.34 & 253 & 81 & 0.32 & 0.3841 & 3.21 & 0.05390 & 1.54 & 0.481 & 338.4 & 5.1 \\
\hline POR8-7 & 0.37 & 204 & 49 & 0.24 & 0.3563 & 4.45 & 0.05411 & 1.57 & 0.353 & 339.7 & 5.2 \\
\hline POR8-10 & 0.06 & 446 & 114 & 0.26 & 0.3955 & 2.08 & 0.05415 & 1.50 & 0.718 & 339.9 & 5.0 \\
\hline POR8-2 & 0.16 & 227 & 91 & 0.40 & 0.3933 & 2.81 & 0.05451 & 1.54 & 0.549 & 342.1 & 5.1 \\
\hline POR8-1.1 & 0.11 & 335 & 122 & 0.36 & 0.3927 & 2.34 & 0.05484 & 1.51 & 0.645 & 344.1 & 5.1 \\
\hline POR10-4A & 2.85 & 31 & 15 & 0.48 & 0.2125 & 25.20 & 0.05008 & 1.82 & 0.072 & 315.0 & 5.6 \\
\hline POR10-11 & 2.80 & 27 & 14 & 0.52 & 0.1931 & 38.61 & 0.05015 & 2.09 & 0.054 & 315.4 & 6.4 \\
\hline POR10-18 & 0.16 & 755 & 706 & 0.94 & 0.3732 & 2.18 & 0.05135 & 1.85 & 0.853 & 322.8 & 5.8 \\
\hline POR10-13 & 1.96 & 36 & 20 & 0.54 & 0.2950 & 14.37 & 0.05137 & 1.69 & 0.117 & 322.9 & 5.3 \\
\hline POR10-3 & 0.70 & 53 & 18 & 0.34 & 0.3454 & 14.10 & 0.05140 & 1.62 & 0.115 & 323.1 & 5.1 \\
\hline POR10-1 & 1.82 & 65 & 29 & 0.44 & 0.2925 & 15.33 & 0.05153 & 1.54 & 0.101 & 323.9 & 4.9 \\
\hline POR10-6 & 0.00 & 114 & 66 & 0.58 & 0.4017 & 6.55 & 0.05192 & 1.34 & 0.204 & 326.3 & 4.3 \\
\hline POR10-2 & 0.00 & 23 & 10 & 0.43 & 0.3856 & 4.52 & 0.05246 & 1.68 & 0.373 & 329.6 & 5.4 \\
\hline POR10-9 & 0.86 & 89 & 34 & 0.38 & 0.3527 & 7.76 & 0.05254 & 1.48 & 0.191 & 330.1 & 4.8 \\
\hline POR10-15 & 0.65 & 118 & 86 & 0.73 & 0.3511 & 6.89 & 0.05258 & 1.44 & 0.209 & 330.3 & 4.6 \\
\hline POR10-19 & 0.00 & 52 & 31 & 0.58 & 0.4161 & 2.92 & 0.05273 & 1.39 & 0.476 & 331.3 & 4.5 \\
\hline POR10-7 & 2.17 & 50 & 25 & 0.49 & 0.2659 & 16.98 & 0.05290 & 1.57 & 0.092 & 332.3 & 5.1 \\
\hline POR10-14 & 0.73 & 117 & 27 & 0.23 & 0.3570 & 5.83 & 0.05292 & 1.29 & 0.221 & 332.5 & 4.2 \\
\hline POR10-10 & 0.30 & 188 & 50 & 0.26 & 0.3693 & 3.56 & 0.05301 & 1.30 & 0.366 & 333.0 & 4.2 \\
\hline POR10-5 & 0.18 & 136 & 34 & 0.25 & 0.3792 & 3.70 & 0.05315 & 1.25 & 0.338 & 333.8 & 4.1 \\
\hline POR10-17 & 0.77 & 41 & 18 & 0.44 & 0.3485 & 18.74 & 0.05348 & 1.80 & 0.096 & 335.9 & 5.9 \\
\hline POR10-12 & 0.25 & 136 & 63 & 0.47 & 0.3908 & 3.59 & 0.05382 & 1.53 & 0.427 & 337.9 & 5.0 \\
\hline POR10-16 & 0.01 & 1247 & 1934 & 1.55 & 0.3949 & 1.29 & 0.05384 & 1.14 & 0.884 & 338.1 & 3.8 \\
\hline POR10-20 & 0.03 & 177 & 58 & 0.33 & 0.4001 & 2.52 & 0.05420 & 1.33 & 0.527 & 340.2 & 4.4 \\
\hline POR10-8 & 0.09 & 427 & 427 & 1.00 & 0.3988 & 1.76 & 0.05421 & 1.17 & 0.662 & 340.3 & 3.9 \\
\hline POR $11 \mathrm{~A}-12.1^{\mathrm{a}}$ & 1.94 & 198 & 75 & 0.38 & 0.2680 & 8.95 & 0.04721 & 1.26 & 0.141 & 297.4 & 3.7 \\
\hline POR $11 \mathrm{~A}-15.1^{\mathrm{a}}$ & 0.89 & 1647 & 1054 & 0.64 & 0.3631 & 2.15 & 0.05084 & 1.03 & 0.478 & 319.7 & 3.2 \\
\hline POR $11 \mathrm{~A}-2.2^{\mathrm{a}}$ & 0.31 & 592 & 342 & 0.58 & 0.3699 & 2.45 & 0.05134 & 1.06 & 0.434 & 322.8 & 3.3 \\
\hline POR11-14.1 & 1.37 & 450 & 305 & 0.68 & 0.3265 & 4.65 & 0.05189 & 1.10 & 0.237 & 326.1 & 3.5 \\
\hline POR11-3.1A & 0.36 & 615 & 297 & 0.48 & 0.3783 & 2.21 & 0.05193 & 1.06 & 0.478 & 326.4 & 3.4 \\
\hline POR11A-18.1 & 1.81 & 525 & 515 & 0.98 & 0.3557 & 6.52 & 0.05213 & 1.13 & 0.173 & 327.6 & 3.6 \\
\hline POR11-18.1 & 0.63 & 505 & 215 & 0.43 & 0.3771 & 2.82 & 0.05214 & 1.08 & 0.382 & 327.6 & 3.4 \\
\hline POR11-13.2 & 2.28 & 290 & 14 & 0.05 & 0.3302 & 10.30 & 0.05219 & 1.22 & 0.118 & 327.9 & 3.9 \\
\hline POR11-12.1 & 0.56 & 534 & 286 & 0.53 & 0.3612 & 2.74 & 0.05259 & 1.07 & 0.391 & 330.4 & 3.4 \\
\hline POR11-16.1 & 0.91 & 275 & 131 & 0.48 & 0.3428 & 5.60 & 0.05269 & 1.17 & 0.209 & 331.0 & 3.8 \\
\hline POR11A.17.1 & 1.53 & 313 & 342 & 1.09 & 0.3514 & 6.42 & 0.05274 & 1.18 & 0.183 & 331.3 & 3.8 \\
\hline POR11-6.1 & 0.70 & 434 & 319 & 0.74 & 0.3594 & 3.48 & 0.05297 & 1.10 & 0.318 & 332.8 & 3.6 \\
\hline POR11-2.2 & 0.79 & 339 & 173 & 0.51 & 0.3729 & 4.02 & 0.05303 & 1.13 & 0.281 & 333.1 & 3.7 \\
\hline POR11-17.1 & 1.00 & 362 & 185 & 0.51 & 0.3419 & 5.04 & 0.05306 & 1.23 & 0.244 & 333.3 & 4.0 \\
\hline POR11A-10.1 & 5.84 & 760 & 696 & 0.92 & 0.3908 & 6.67 & 0.05327 & 1.21 & 0.181 & 334.5 & 3.9 \\
\hline POR11-5.2 & 0.45 & 672 & 327 & 0.49 & 0.3728 & 2.49 & 0.05328 & 1.05 & 0.423 & 334.6 & 3.4 \\
\hline POR11A-14.1 & 4.61 & 1004 & 612 & 0.61 & 0.3508 & 11.97 & 0.05335 & 1.25 & 0.105 & 335.1 & 4.1 \\
\hline POR11A-4.2 & 0.38 & 333 & 246 & 0.74 & 0.3903 & 3.95 & 0.05341 & 1.55 & 0.392 & 335.4 & 5.1 \\
\hline POR11-8.1 & 0.48 & 674 & 332 & 0.49 & 0.3838 & 2.22 & 0.05360 & 1.12 & 0.507 & 336.6 & 3.7 \\
\hline POR11-10.1 & 1.02 & 249 & 204 & 0.82 & 0.3343 & 5.97 & 0.05371 & 1.18 & 0.198 & 337.3 & 3.9 \\
\hline POR11-9.1 & 2.69 & 132 & 92 & 0.70 & 0.2523 & 18.44 & 0.05376 & 1.47 & 0.080 & 337.6 & 4.8 \\
\hline POR11-1.1 & 0.35 & 831 & 494 & 0.59 & 0.3740 & 2.14 & 0.05397 & 1.04 & 0.486 & 338.8 & 3.4 \\
\hline POR11A-13.1 & 1.36 & 746 & 757 & 1.01 & 0.3832 & 3.83 & 0.05402 & 1.07 & 0.279 & 339.1 & 3.5 \\
\hline POR11A-8.2 & 1.05 & 291 & 92 & 0.32 & 0.3515 & 5.17 & 0.05404 & 1.15 & 0.223 & 339.3 & 3.8 \\
\hline POR11A-16.1 & 0.99 & 362 & 166 & 0.46 & 0.3732 & 3.92 & 0.05404 & 1.14 & 0.289 & 339.3 & 3.8 \\
\hline
\end{tabular}


Table 1. (continued)

\begin{tabular}{|c|c|c|c|c|c|c|c|c|c|c|c|}
\hline Spot & $\begin{array}{c}{ }^{206} \mathrm{~Pb} \\
(\%)\end{array}$ & $\begin{array}{c}\mathrm{U} \\
(\mathrm{ppm})\end{array}$ & $\begin{array}{c}\mathrm{Th} \\
(\mathrm{ppm})\end{array}$ & $\mathrm{Th} / \mathrm{U}$ & ${ }^{207} \mathrm{~Pb} /{ }^{235} \mathrm{U}$ & $\begin{array}{l}\text { Error } \\
(\%)\end{array}$ & ${ }^{206} \mathrm{~Pb} /{ }^{238} \mathrm{U}$ & $\begin{array}{l}\text { Error } \\
(\%)\end{array}$ & $\begin{array}{c}\text { Error } \\
\text { Correlation }\end{array}$ & $\begin{array}{c}{ }^{206} \mathrm{~Pb} /{ }^{238} \mathrm{U} \\
\text { Age }\end{array}$ & $\pm 1 \sigma$ \\
\hline POR11A-9.1 & 0.61 & 598 & 615 & 1.03 & 0.3858 & 3.26 & 0.05482 & 1.07 & 0.328 & 344.1 & 3.6 \\
\hline POR11-11.1 & 1.20 & 237 & 138 & 0.58 & 0.3487 & 5.99 & 0.05487 & 1.39 & 0.232 & 344.4 & 4.7 \\
\hline POR11-15.1 inh ${ }^{\mathrm{b}}$ & 0.59 & 399 & 489 & 1.23 & 0.7941 & 3.44 & 0.09820 & 1.09 & 0.317 & 604 & 6 \\
\hline POR11-13.1 inh $^{\mathrm{b}}$ & 1.67 & 106 & 64 & 0.60 & 0.6786 & 6.02 & 0.10010 & 1.30 & 0.216 & 615 & 8 \\
\hline POR11-4.2 inh ${ }^{\mathrm{b}}$ & 0.58 & 40 & 38 & 0.95 & 4.3167 & 2.94 & 0.30446 & 1.48 & 0.503 & 1713 & 22 \\
\hline POR11-7.2 inh $^{\mathrm{b}}$ & 0.11 & 659 & 243 & 0.37 & 16.3442 & 1.25 & 0.51729 & 1.03 & 0.823 & 2688 & 23 \\
\hline
\end{tabular}

${ }^{a}$ Data excluded from the age calculation because of suspected $\mathrm{Pb}$ loss.

${ }^{b}$ Here inh indicates inherited core.

clinopyroxene, and accessory titanite, apatite and zircon. The zircons recovered have a more complex internal structure compared to the other samples. The zoning is predominantly broadband oscillatory, but CL-dark and U-rich cores (500-1000 ppm), often motted and fracture-rich are present in many grains. Thin and CL-bright rims are also occasion- ally present. Regardless of the zoning, most analyses define a concordia age of $332 \pm 3$ Ma (Figure 3 and Table 1).

[16] Sample POR-11 is a strongly foliated fine-grained amphibolite made up of amphibole, plagioclase and quartz, with titanite, ore minerals and zircon as accessory phases; sericite, actinolite, and epidote are secondary phases. The
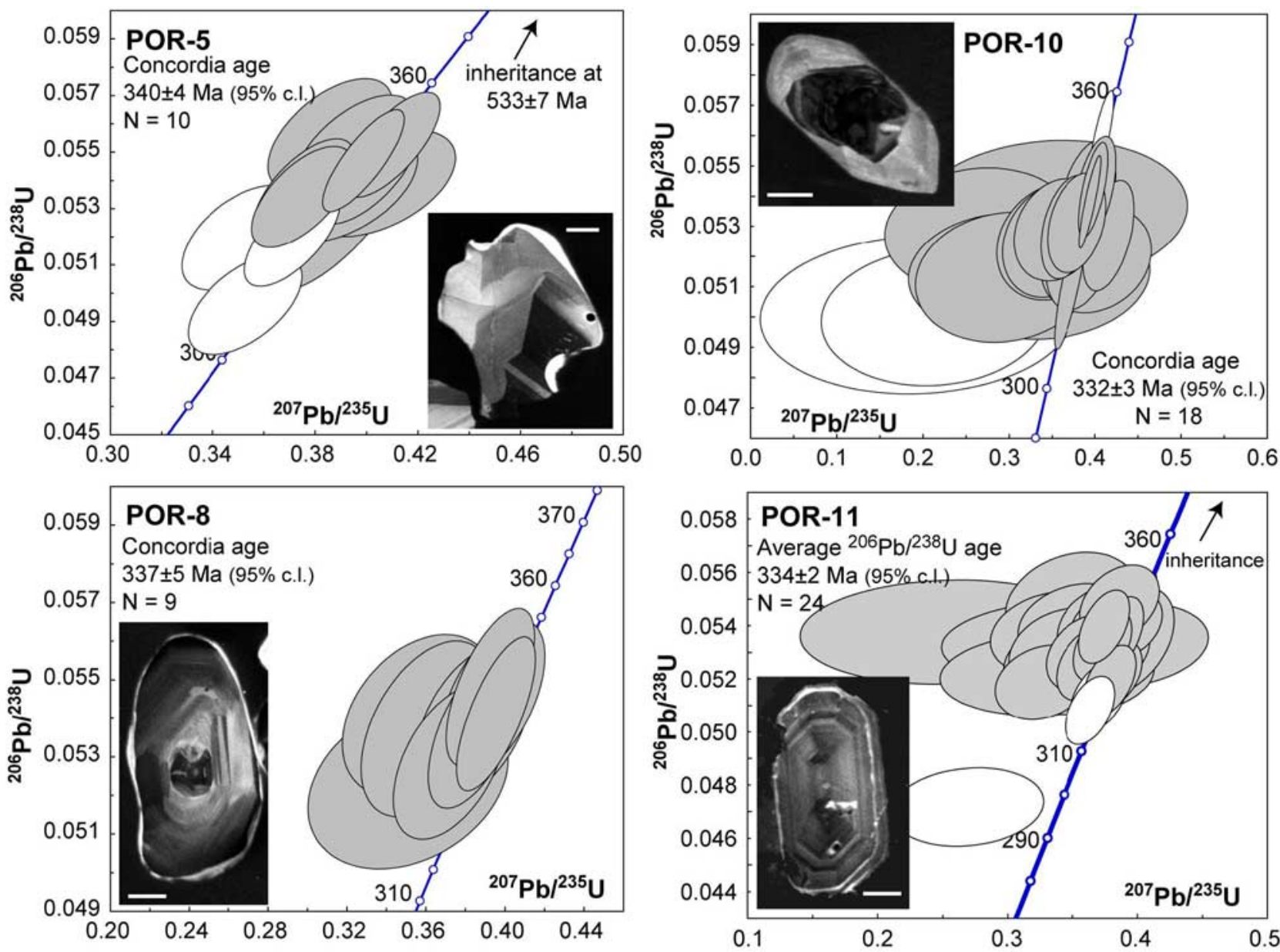

Figure 3. Concordia diagrams for the SHRIMP zircon U-Pb analyses of the four samples. Concordia and average ages are calculated from the analyses plotted as gray ellipses. White ellipses represent analyses suspected of $\mathrm{Pb}$ loss during metamorphism. Data point error ellipses are 2 sigma. The inset in each diagram is a cathodoluminescence image of a representative zircon crystal in the corresponding sample. The scale bar corresponds to $20 \mu \mathrm{m}$. 
zircon crystals have color and shape similar to the other samples, with a prevalence of euhedral grains. CL zoning varies from broad to fine oscillatory, with a few grains displaying sector zoning and others preserving distinct cores. Occasionally, CL-dark rims are preserved, whose size is, however, below the resolution of SHRIMP analysis. The zircons generally have medium to high $U$ and $T h$ contents (Table 1) with $\mathrm{Th} / \mathrm{U}$ in the range $0.4-1.1$. Most analyses cluster in a group plotted slightly off the Concordia, possibly because of an analytical offset in measuring the ${ }^{207} \mathrm{~Pb} /{ }^{235} \mathrm{U}$ ratio. Therefore, the average ${ }^{206} \mathrm{~Pb} /{ }^{238} \mathrm{U}$ age of $334 \pm 2 \mathrm{Ma}$ (Figure 3 ) is taken here as the best estimate of the crystallization of the protolith. A few grains with poor zoning yielded slightly younger ages, while the distinct cores yielded inherited ages (0.6 to $2.5 \mathrm{Ga}$, Table 1$)$.

\section{Discussion}

[17] The geochronological data obtained in this work provide a time framework for the MORB-featured amphibolitic unit that constitutes the boundary between the $\mathrm{OMZ}$ and SPZ, thus questioning the correlation of ophiolitic units along the Variscan-Alleghanian Orogen. In sections 5.15.4 , we tackle the implications of our new ages for the timing of MORB-featured mafic magmatism and low-pressure metamorphism in southern Iberia, the Rheic Ocean reconstructions and the correlation of Variscan ophiolitic units. Finally, we propose an evolutionary model for southern Iberia during the Late Paleozoic, integrating these new radiometric ages with the geological and geophysical data available.

\subsection{Timing of Mafic Magmatism and Low-Pressure Metamorphism}

[18] The zircons dated show the typical internal zoning (broadband oscillatory) and chemistry (high $\mathrm{Th} / \mathrm{U}$ of $0.3-1.1)$ commonly observed in magmatic zircons from mafic rocks [e.g., Rubatto and Gebauer, 2000; Corfu et al., 2003]. Therefore we interpret the ages obtained from the main population of zircon grains as dating the crystallization of the BAA protoliths. A limited number of analyses recording apparent younger ages (Figure 3 and Table 1) likely represent a partial disturbance of the $\mathrm{U}-\mathrm{Pb}$ system during the later amphibolite facies metamorphism. Our data do not offer however any further constraints on the timing of metamorphism. It is worth noting that some of the samples (POR-5 and POR-11) contain a few older zircon grains or cores. These zircons either have a xenocrystic origin (isolated grains incorporated into the gabbroic rocks by assimilation of host rocks during magma ascent) or are inherited from the magma source (cores overgrown by magmatic zircons). Such contamination of the magmatic zircon population, as well as the eventual $\mathrm{Pb}$ loss associated with metamorphism, would not be easily detected by isotope dilution analyses of zircon grains. This fact justifies by itself the use of SHRIMP microanalysis, despite the possible detriment of precision.

[19] The ages obtained for the protoliths of the BAA unit range from $340 \pm 4$ to $332 \pm 3 \mathrm{Ma}$. Independently of the precise tectonic scenario invoked (arc-related basin, midocean ridge, or even intracontinental magmatism during extensional tectonics), these protolith ages allow the conclusion that the BAA gabbroic rocks correspond to an Early Carboniferous magmatic event and not to the OrdovicianDevonian Rheic Ocean, which, in turn, has a number of important consequences.

[20] The ages reported here (340-332 Ma) are only in part younger than the ones available for the Beja Gabbros (352-342 Ma [Pin et al., 1999; Jesus et al., 2007]). The shift toward older ages in the first geochronology done on the Beja Gabbro (350-352 Ma [Pin et al., 1999]) is probably due to the presence of some inheritance (as observed in our study on the BAA unit) not detected by conventional isotope dilution analysis. The combined data open the possibility that the BAA unit, the Beja Gabbros and other plutonic rocks of the same age in the OMZ may be part of the same magmatic event. Moreover, the Early Carboniferous period in southern Iberia is characterized by abundant bimodal volcanism hosting massive sulphide deposits in the so-called Iberian Pyrite Belt of the SPZ [Schermerhorn, 1971; Leistel et al., 1997; Nesbitt et al., 1999; Sáez et al., 1999] and thick flysch sedimentation both in the southern part of the CIZ and the whole SPZ [Oliveira, 1990; Giese et al., 1994; Martinez Poyatos et al., 1995]. Accordingly, the general tectonic regime in southern Iberia at Early Carboniferous times seems to be an extensional/ transtensional one (see below), where volcanism, gabbroic magma formation (Beja Gabbros), ephemeral oceanic crust generation (BAA unit) and deep-water marine sedimentation would have occurred on a thinned continental crust.

[21] The metamorphism ages available for the BAA unit, which likely date the amphibolite to greenschist facies event affecting it, span a time period between 342 and $328 \mathrm{Ma}$ [Dallmeyer et al., 1993; Castro et al., 1999]. Therefore, the older metamorphism ages seem to be unrealistic, since they overlap with our protolith ages. On the contrary, the younger metamorphism ages are compatible with our protolith ages, indicating that deformation/metamorphism of the BAA rocks occurred shortly after its formation.

\subsection{Implications for the Rheic Ocean Paleogeography}

[22] The geochemical signature of the BAA rocks has been mostly attributed to an origin in a back-arc or intra-arc basin developed in a suprasubduction zone setting [Quesada et al., 1994], although a mid-ocean ridge has also been suggested [Castro et al., 1996]. The latter scenario is very unlikely due to the short time span between the formation of the BAA unit (circa 332-340 Ma, this work) and its exhumation (circa $330 \mathrm{Ma}$, considering as valid the youngest ${ }^{40} \mathrm{Ar} /{ }^{39} \mathrm{Ar}$ ages [Castro et al., 1999]). As for the backarc or intra-arc basin in a suprasubduction zone setting, the Early Carboniferous ages reported here might be interpreted as being related to the very final stages of Rheic Ocean consumption. Nevertheless, the palynological content of Upper Devonian and Lower Carboniferous sediments at both sides of the BAA unit is similar [Pereira et al., 2006], thus, suggesting that the OMZ and SPZ were already welded in Late Devonian times. This implies that the Rheic 
(a) 390 - $345 \mathrm{Ma}$ 1st Collisional event

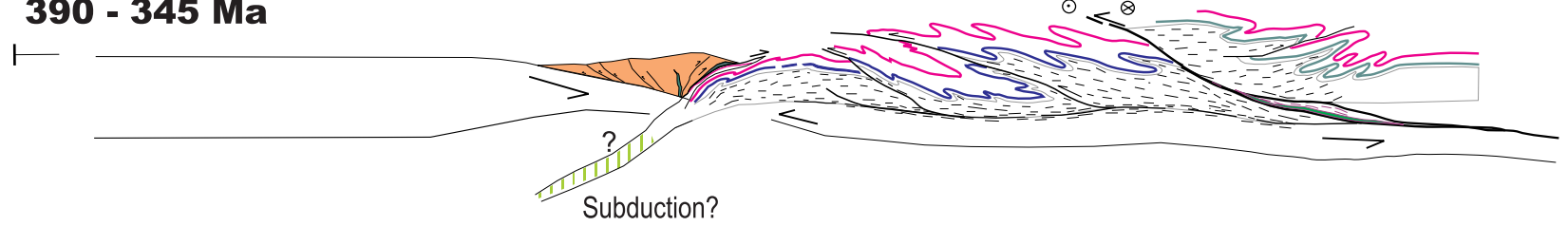

(b)

Transient extensional/transtensional event

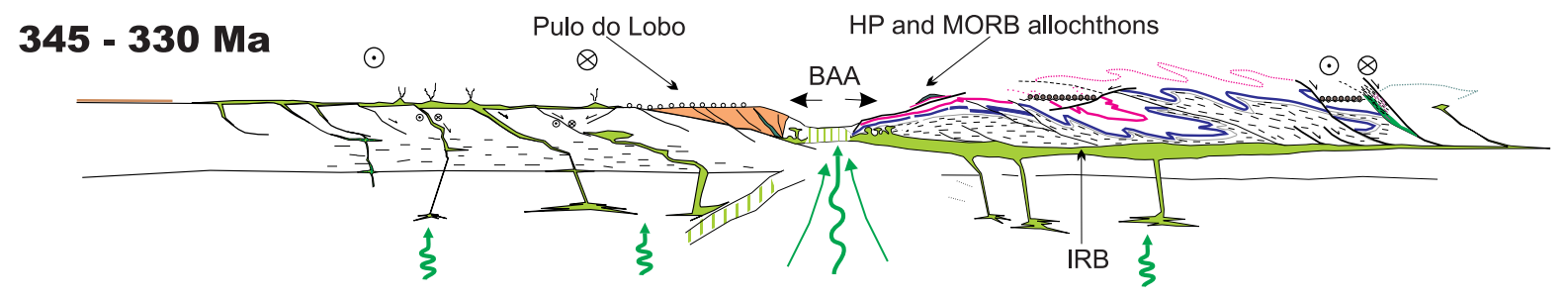

(C)

330 - 305 Ma

2nd Collisional event

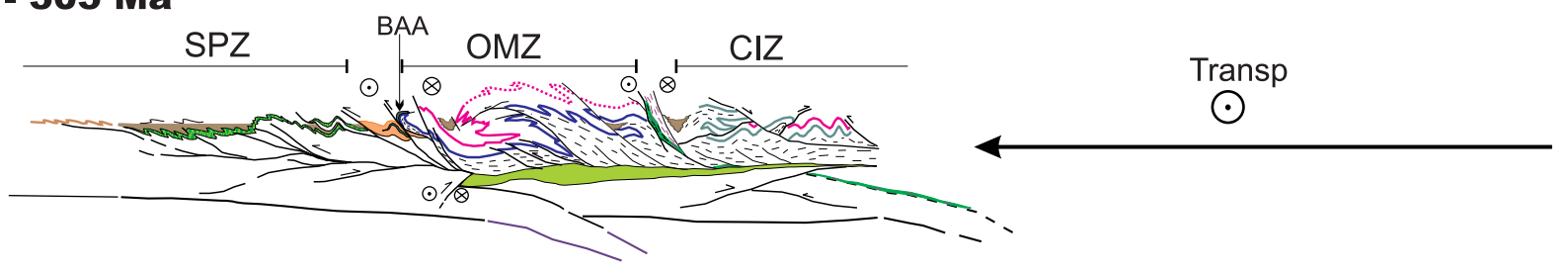

$100 \mathrm{~km}$ (approx.)

Figure 4. Evolutionary model for southern Iberia from Middle-Late Devonian to Late Carboniferous. (a) The first collisional event propagated NE and SW from the boundary between the Central Iberian and Ossa-Morena zones giving way to recumbent folds and thrusts in the upper crust. (b) The Early Carboniferous transient extensional/transtensional event was characterized by abundant mafic magmatism and thick flysch sedimentation. During this stage a huge volume of mafic rocks were trapped in the middle crust of the Ossa-Morena Zone, generating an irregular highly reflective body, namely, the Iberian reflective body (IRB). Intense and localized extension in the boundary between the Ossa-Morena and South Portuguese zones was responsible for the formation of the MORB-featured BejaAcebuches amphibolites (BAA). (c) Renewal of the shortening during the second collisional event in Late Carboniferous times under a transpressional tectonic regime produced the final crustal geometry of southern Iberia. This cross section has been depicted taking into account the surface geology data and the seismic image provided by IBERSEIS.

Ocean, if present along this boundary, must have been consumed previously. In other words, the BAA unit cannot represent an oceanic realm related to the Rheic Ocean. Therefore, we favor the interpretation of the BAA unit as a narrow and very ephemeral realm of oceanic-like crust, independent from the Rheic Ocean and generated after its consumption (Figure 4). The extreme narrowness of this domain is favored by the palynological data [Pereira et al., 2006] and indirectly by the presence of Cambrian inherited zircons in one of the dated gabbros, which could have been assimilated from surrounding continental rocks. In the same way, the geochemical data provided by Pin et al. [1999], which were interpreted in terms of a mixture of rocks with different origins, are now well understood in this context where oceanic and continental rocks could have been easily amalgamated.

[23] Our new data show that the Rheic suture is not represented at all in the BAA unit and cast some doubts on the tectonic meaning of the OMZ/SPZ boundary. Nevertheless, the OMZ/SPZ might still represent a criptic Rheic suture, the BAA unit having been formed after the total consumption of the Rheic Ocean. On this view, the small 
and dispersed fragments of MORB-featured mafic rocks both to the north (in southwest OMZ) and south (in the Pulo do Lobo unit) of the BAA unit remain as putative Rheicrelated suture rocks. However, no absolute ages are available on these MORB-featured rocks.

\subsection{Correlations With Other Variscan Ophiolites}

[24] Up to now, Variscan ophiolites across Europe have been arranged into two groups according to their ages: Early Paleozoic ophiolites $(\approx 470-497$ Ma [e.g., Ordónez-Casado et al., 2001; Arenas et al., 2007b]) and Devonian ophiolites ( $\approx 395-400$ Ma [e.g., Díaz García et al., 1999; Nutman et al., 2001; Pin et al., 2006]). Early Paleozoic ophiolites may attest the Rheic Ocean opening, while Devonian ophiolites may attest minor (mostly suprasubduction) oceanic realms formed during intraoceanic subduction of the Rheic Ocean [Sánchez Martínez et al., 2007; Arenas et al., 2007b]. The Early Carboniferous ages reported here for the BAA unit are the youngest ones among the Variscan ophiolites, thus preventing direct correlation with any other ophiolites in this orogen. Similarly, the tectonic models joining in a single suture line the BAA unit in southern Iberia to either the Lizard ophiolite in southern England [e.g., CrespoBlanc and Orozco, 1991; Matte, 2001] or the root zone of the allochthonous ophiolitic units in northwest Iberia [e.g., Ribeiro et al., 2007] must be reconsidered because of the above mentioned age difference.

\subsection{Integrating the Beja-Acebuches Amphibolites in the Southern Iberia Tectonic Evolution}

[25] The Early Carboniferous ages of the BAA protoliths, together with their oceanic affinity and temporal coincidence with conspicuous basic magmatism and thick sedimentation throughout all southern Iberia, constitute main fundamentals when trying to establish a reliable tectonic scenario. An extensional/transtensional setting unrelated to any putative pre-Carboniferous suprasubduction zone context seems the most plausible one (see below). Such extensional/transtensional Early Carboniferous stage would have been preceded by an essentially Middle-Late Devonian collisional event characterized by the formation of kilometer-scale recumbent folds (Figure 4a) affecting the entire OMZ and the southern part of the CIZ [Simancas et al., 2001, 2003; Expósito et al., 2002]. This first collisional event propagated from the OMZ/CIZ contact both to the north (southern part of the CIZ) and south (OMZ), thus attesting continental subduction of the OMZ crust underneath the CIZ crust (Figure 4a) as shown in the seismic profile IBERSEIS [Simancas et al., 2003]. Pre-Devonian evolution of this boundary is inferred from geochronology and geochemistry of the amphibolites intercalated in the Central Unit, which suggest the existence of a narrow oceanic domain in Early Paleozoic times between OMZ and CIZ continental blocks, which would have been consumed by subduction previously to the continental subduction and collision. As for the OMZ/SPZ contact, two possible scenarios are plausible in Middle-Late Devonian: (1) the final stages of Rheic ocean consumption were occurring as suggested in Figure $4 a$; the remnants of this subduction would not be the BAA ophiolitic unit, though the MORB-featured basalts included in the Pulo do Lobo unit to the south of the OMZ/SPZ contact and the slices of mafic rocks with high-pressure metamorphism and/or ophiolitic affinity to the north of the OMZ/SPZ contact may well attest the Rheic Ocean subduction; and (2) the Rheic Ocean was not present between the OMZ and SPZ, being both part of a single continental block with two domains, one affected by the OMZ/CIZ collision to the north (OMZ) and one another not affected by the southward propagation of this collision (SPZ); in this second scenario the SPZ would record a continuous marine sedimentation all along the Devonian in a passive continental margin. The lack of protolith ages in the suspected Rheic Ocean remnants makes it impossible to discard one of these two options.

[26] The extensional/transtensional event responsible for the formation of the BAA ophiolitic unit may represent a transient stage after the first collisional stage. Thus, the BAA MORB-featured unit could have been generated in a very ephemeral and narrow oceanic domain open during this extensional/transtensional event (Figure 4b). This event could also have been responsible for the abundant mafic magmatism both in the OMZ (plutonic rocks) and SPZ (mainly volcanic rocks with associated massive sulfide deposits in the so-called Iberian Pyrite Belt), as well as thick flysch sedimentation both in the SPZ and the southern part of the CIZ. The interpretation proposed here for the BAA unit is in some ways similar to that made by Bard [1977], who envisaged intracontinental rifting as a possible setting of this unit.

[27] To find the reason for the change in the tectonic regime from compression to extension/transtension, one needs to consider together surface geology data and deep crustal features. The IBERSEIS seismic profile provides an image of southern Iberia crust in a SW-NE transect. The most striking seismic structure imaged in the OMZ is a long, thick, irregular, strongly reflective band in the middle crust, namely, the IBERSEIS Reflective Body (IRB, Figures $4 \mathrm{~b}$ and $4 \mathrm{c}$ ). This band contains small domains of layered reflectivity interfingering at different dips, which have been interpreted as an Early Carboniferous rock layering of differentiated mafic igneous bodies intruding rocks with different degrees of assimilation [Simancas et al., 2003, 2006]. A mantle plume affecting all of the European Variscan Belt and maybe the northern Appalachians [Murphy and Keppie, 2005] in Early Carboniferous times is the most plausible large-scale geodynamic scenario for all the above mentioned features, including the formation of MORB-featured rocks.

[28] Variscan collisional tectonics resumed after the Early Carboniferous transient extensional/transtensional stage. This second collisional stage had a general transpressional character in southern Iberia [e.g., Simancas et al., 2006], with the strain partitioned among upright folds, oblique thrusts and left-lateral strike-slip faults (Figure 4c). Thus, the very narrow oceanic domain represented by the BAA unit was closed and exhumed shortly after formation by the renewal of the convergence, generating the penetrative 
planar-linear fabric affecting the rocks of this unit. Accordingly, the formation of the BAA rocks and the intrusion of the Beja Gabbros, as well as the high-temperature/lowpressure metamorphism and the shear zone affecting the BAA unit, occurred within a short-lived 20 Ma long episode in Early Carboniferous times.

[29] The evolution envisaged here in southern Iberia can be compared with the one of the central European Variscides. The OMZ/SPZ contact has been correlated with the Rheno-Hercynian/Saxo-Thuringian boundary in central Europe, where after Middle Devonian consumption of the Rheic Ocean in between these two zones, extensional tectonics gave way to a bimodal volcanism and the opening of a new small ocean, namely, the Rheno-Hercynian Ocean [Franke, 2000], which, in turn, was closed in earliest Carboniferous times. According to the ages reported here, the BAA unit of southern Iberia cannot be the equivalent of any of the suture units found in the Rheno-Hercynian/SaxoThuringian boundary. Interestingly, the Rheno-Hercynian zone itself, which represents the foreland of the Variscan
Belt in Germany (Avalonia), contains Early Carboniferous tholeiitic E-type MORB-featured mafic pillow lavas. These volcanics are clearly unrelated to a suprasubduction zone scenario, since the Devonian Rheno-Hercynian Ocean was already being subducted southward in Early Carboniferous times under one of the fragments of the Armorica microplate. Therefore, they might be associated with the magmatic event responsible for the formation of the BAA unit and other mafic rocks in southern Iberia.

[30] Acknowledgments. The Electron Microscopy Unit at the ANU is thanked for access to the SEM facilities. This research was supported by the Spanish Ministry of Education and Science through grants BTE200305128, CGL2007-63101/BTE, and TOPO-IBERIA CONSOLIDERINGENIO CSD2006-00041, all of them partially financed with FEDER funds of the European Community. We thank Paulo Fonseca for field assistance during sample collection and Francisco Gonzálvez García for reviewing the English text. Cathy Busby is kindly acknowledged for a critical reading of the manuscript. Reviews made by Ricardo Arenas and Wolfgang Franke are greatly appreciated.

\section{References}

Abalos, B., J. I. Gil Ibarguchi, and L. Eguíluz (1991), Cadomian subduction/collision and Variscan transpression in the Badajoz-Córdoba shear belt, southwest Spain, Tectonophysics, 199, 51-72, doi:10.1016/ 0040-1951(91)90118-C.

Araújo, A., P. Fonseca, J. Munhá, P. Moita, J. Pedro, and A. Ribeiro (2005), The Moura Phyllonitic Complex: An accretionary complex related with obduction in the southern Iberia Variscan suture, Geodin. Acta, 18, 375-388, doi:10.3166/ga.18.375-388.

Arenas, R., J. R. Martínez Catalán, S. Sánchez Martínez, F. Díaz García, J. Abati, J. FernándezSuárez, P. Andonaegui, and J. Gómez-Barreiro (2007a), Paleozoic ophiolites in the Variscan suture of Galicia (northwest Spain): Distribution, characteristics and meaning, in 4-D Framework of Continental Crust, edited by R. D. Hatcher et al., Mem. Geol. Soc. Am., 200, $425-444$.

Arenas, R., J. R. Martínez Catalán, S. Sánchez Martínez, J. Fernández-Suárez, P. Andonaegui, J. A. Pearce, and F. Corfu (2007b), The Vila de Cruces Ophiolite: A remnant of the early Rheic Ocean in the Variscan suture of Galicia (northwest Iberian Massif), J. Geol., 115, 129-148, doi:10.1086/510645.

Azor, A., F. González Lodeiro, and J. F. Simancas (1994), Tectonic evolution of the boundary between the Central Iberian and Ossa-Morena zones (Variscan Belt, SW Spain), Tectonics, 13, 45-61, doi: $10.1029 / 93$ TC02724.

Bard, J. P. (1977), Signification tectonique des métatholeites d'affinité abyssale de la ceinture de basse pression d'Aracena (Huelva, Espagne), Bull. Soc. Geol. Fr. 19, 385-393.

Bard, J. P., and B. Moine (1979), Acebuches amphibolites in the Aracena Hercynian metamorphic belt (southern Spain): Geochemical variations and basaltic affinities, Lithos, 12, 271-282, doi:10.1016/ 0024-4937(79)90018-5.

Booth-Rea, G., J. F. Simancas, A. Azor, J. M. Azañón, F. González Lodeiro, and P. Fonseca (2006), HPLT Variscan metamorphism in the Cubito-Moura schists (Ossa-Morena Zone, southern Iberia), C. $R$. Geosci., 338, 1260-1267, doi:10.1016/j.crte.2006. 08.001 .

Burg, J. P., M. Iglesias, P. Laurent, P. Matte, and A. Ribeiro (1981), Variscan intracontinental deformation: The Coimbra-Córdoba Shear Zone (SW Iberian Peninsula), Tectonophysics, 78, 161-177, doi:10.1016/0040-1951(81)90012-3.
Castro, A., C. Fernández, J. De la Rosa, I. MorenoVentas, and G. Rogers (1996), Significance of MORB-derived Amphibolites from the Aracena Metamorphic Belt, southwest Spain, J. Petrol., 37, 235-260, doi:10.1093/petrology/37.2.235.

Castro, A., C. Fernández, H. El-Hmidi, M. El-Biad, M. Díaz Azpiroz, J. de la Rosa, and F. Stuart (1999), Age constraints to the relationships between magmatism, metamorphism and tectonism in the Aracena metamorphic belt, southern Spain, Int. $J$. Earth Sci., 88, 26-37, doi:10.1007/s005310050243.

Cocks, L. R. M., and T. H. Torsvik (2006), European geography in a global context from the Vendian to the end of the Palaeozoic, in European Lithosphere Dynamics, edited by D. G. Gee and R. A. Stephenson, Mem. Geol. Soc., 32, 83-95.

Corfu, F., J. M. Hanchar, P. W. O. Hoskin, and P. D. Kinny (2003), Atlas of zircon texture, in Zircon, Rev. Mineral. Geochem., vol. 53, edited by J. M. Hanchar and P. W. O. Hoskin, pp. 469-500, Mineral. Soc. of Am., Washington, D. C.

Crespo-Blanc, A., and M. Orozco (1991), The boundary between the Ossa-Morena and South Portuguese zones (southern Iberian Massif): A major suture in the European Hercynian Chain, Geol. Rundsch., 80, 691-702, doi:10.1007/BF01803695.

Dallmeyer, R. D., P. E. Fonseca, C. Quesada, and A. Ribeiro (1993), ${ }^{40} \mathrm{Ar} /{ }^{39} \mathrm{Ar}$ mineral age constraints for the tectonothermal evolution of a Variscan suture in southwest Iberia, Tectonophysics, 222, 177-194, doi:10.1016/0040-1951(93)90048-O.

Díaz García, F., R. Arenas, J. R. Martínez Catalán, J. González del Tanago, and G. R. Dunning (1999), Tectonic evolution of the Careón ophiolites (northwest Spain): A remnant of oceanic lithosphere in the Variscan belt, J. Geol., 107, 587-605, doi:10.1086/ 314368.

Eden, C., and J. Andrews (1990), Middle to upper Devonian melanges in SW Spain and their relationship to the Meneage formation in south Cornwall, Proc. Ussher Soc., 7, 217-222.

Expósito, I., J. F. Simancas, F. González Lodeiro, A. Azor, and D. J. Martínez Poyatos (2002), Estructura de la mitad septentrional de la zona de OssaMorena: Deformación en el bloque inferior de un cabalgamiento cortical de evolución compleja, Rev. Soc. Geol. Esp., 15, 3-14.

Fonseca, P., and A. Ribeiro (1993), Tectonics of the Beja-Acebuches ophiolite: A major suture in the
Iberian Variscan Foldbelt, Geol. Rundsch., 82, 440 - 447, doi:10.1007/BF00212408.

Fonseca, P., J. Munhá, J. Pedro, F. Rosas, P. Moita, A. Aráujo, and N. Leal (1999), Variscan ophiolites and high-pressure metamorphism in southern Iberia, Ofioliti, 24, 259-268.

Franke, W. (2000), The mid-European segment of the Variscides: Tectonostratigraphic units, terrane boundaries and plate tectonic evolution, in Orogenic Processes: Quantification and Modelling in the Variscan Belt, edited by W. Franke et al., Geol. Soc. Spec. Publ., 179, 35-61.

Giese, U., R. V. Hoegen, G. Hollmann, and R. Walter (1994), Geology of the southwestern Iberian Meseta. I: The Paleozoic of the Ossa-Morena Zone north and south of the Olivenza-Monesterio Anticline (Huelva province, SW Spain), Neues Jahrb. Geol. Palaeontol. Abh., 192, 293-331.

Gómez-Pugnaire, M. T., A. Azor, J. M. FernándezSoler, and V. López Sánchez-Vizcaíno (2003), The amphibolites from the Ossa-Morena/Central Iberian Variscan suture (southwestern Iberian Massif): Geochemistry and tectonic interpretation, Lithos, 68, 23 -42, doi:10.1016/S0024-4937(03)00018-5.

Jesus, A. P., J. Munhá, A. Mateus, C. Tassinari, and A. P. Nutman (2007), The Beja layered gabbroic sequence (Ossa-Morena Zone, southern Portugal): Geochronology and geodynamic implications, Geodin. Acta, 20, 139-157, doi:10.3166/ga.20. 139-157.

Leistel, J. M., E. Marcoux, D. Thiéblemont, C. Quesada, A. Sánchez, G. R. Almodóvar, E. Pascual, and R. Sáez (1997), The volcanic-hosted massive sulphide deposits of the Iberian Pyrite Belt, Miner. Deposita, 33, 2-30, doi:10.1007/s001260050130.

Linnemann, U., N. J. McNaughton, R. L. Romer, M. Gehmlich, K. Drost, and C. Tonk (2004), West African provenance for Saxo-Thuringia (Bohemian Massif): Did Armorica ever leave pre-Pangean Gondwana?-U/Pb-SHRIMP zircon evidence and the Nd-isotopic record, Int. J. Earth Sci., 93, 683-705, doi:10.1007/s00531-004-0413-8.

López Sánchez-Vizcaino, V., M. T. Gómez-Pugnaire, A. Azor, and J. M. Fernández-Soler (2003), Phase diagram sections applied to amphibolites: A case study from the Ossa-Morena/central Iberian Variscan suture (southwestern Iberian Massif), Lithos, 68, 1-21, doi:10.1016/S0024-4937(03)00017-3.

Martínez Catalán, J. R., R. Arenas, F. Díaz García, and J. Abati (1997), Variscan accretionary complex of 
northwest Iberia: Terrane correlation and succession of tectonothermal events, Geology, 25, 1103-1106, doi:10.1130/0091-7613[1997]025<1103:VACONI $>$ 2.3. $\mathrm{CO} ; 2$.

Martínez Poyatos, D. J., J. F. Simancas, A. Azor, and F. González Lodeiro (1995), La estructura del borde meridional de la Zona Centroibérica en el sector suroriental de la Provincia de Badajoz, Rev. Soc. Geol. Esp., 8, 41-50.

Matte, P. (2001), The Variscan collage and orogeny $(480-290 \mathrm{Ma})$ and the tectonic definition of the Armorica microplate: A review, Terra Nova, 13, $122-128$, doi:10.1046/j.1365-3121.2001.00327.x.

Murphy, J. B., and J. D. Keppie (2005), The Acadian Orogeny in the northern Appalachians, Int. Geol. Rev., 47, 663-687, doi:10.2747/0020-6814.47.7. 663

Nesbitt, R. W., E. Pascual, C. M. Fanning, M. Toscano, R. Sáez, and G. R. Almodóvar (1999), U-Pb dating of stockwork zircons from the eastern Iberian Pyrite Belt, J. Geol. Soc., 156, 7-10, doi:10.1144/gsjgs. 156.1.0007.

Nutman, A. P., D. H. Green, C. A. Cook, M. T. Styles, and R. E. Holdsworth (2001), SHRIMP U-Pb zircon dating of the exhumation of the Lizard Peridotite and its emplacement over crustal rocks: Constraints for tectonic models, J. Geol. Soc., 158 , $809-820$.

Nysæther, E., T. H. Torsvik, R. Feist, H. J. Walderhaug, and E. A. Eide (2002), Ordovician palaeogeography with new palaeomagnetic data from the Montagne Noir (southern France), Earth Planet. Sci. Lett., 203, 329-341, doi:10.1016/S0012-821X(02) 00847-6.

Oliveira, J. T. (1990), Part VI: South Portuguese Zone, stratigraphy and synsedimentary tectonism, in Pre-Mesozoic Geology of Iberia, edited by R. D. Dallmeyer and E. Martínez-García, pp. 334-347, Springer, New York, USA.

Ordóñez-Casado, B. (1998), Geochronological studies of the Pre-Mesozoic basement of the Iberian Massif: The Ossa-Morena zone and the Allochthonous Complexes within the Central Iberian zone, Ph.D. thesis, 235 pp., Eidg. Tech. Hochsch., Zurich, Switzerland

Ordóñez-Casado, B., D. Gebauer, H. J. Schäfer, J. I. Gil Ibarguchi, and J. J. Peucat (2001), A single Devonian subduction event for the HP/HT metamorphism of the Cabo Ortegal complex within the Iberian Massif,
Tectonophysics, 332, 359-385, doi:10.1016/S00401951(00)00210-9.

Pereira, Z., V. Oliveira, and J. T. Oliveira (2006), Palynostratigraphy of the Toca da Moura and Cabrel complexes, Ossa Morena Zone, Portugal. Geodynamic implications, Rev. Palaeobot. Palynol., 139 227-240, doi:10.1016/j.revpalbo.2005.07.008

Pérez-Estaún, A., J. R. Martínez Catalán, and F. Bastida (1991), Crustal thickening and deformation sequence in the footwall to the suture of the Variscan belt of northwest Spain, Tectonophysics, 191 243-253, doi:10.1016/0040-1951(91)90060-6.

Pin, C., J. L. Paquette, and P. Fonseca (1999), 350 (U-Pb zircon) igneous emplacement age and $\mathrm{Sr}-\mathrm{Nd}$ isotopic study of the Beja Gabbroic complex (S Portugal), paper presented at XV Reunión de Geología de Oeste Peninsular, Univ. of Extremadura at Badajoz, Badajoz, Spain.

Pin, C., J. L. Paquette, B. Abalos, F. J. Santos, and J. I. Gil Ibarguchi (2006), Composite origin of an early Variscan transported suture: Ophiolitic units of the Morais Nappe Complex (north Portugal), Tectonics, 25, TC5001, doi:10.1029/2006TC001971.

Quesada, C. (1991), Geological constraints on the Paleozoic tectonic evolution of tectonostratigraphic Terranes in the Iberian Massif, Tectonophysics, 185 , 225-245, doi:10.1016/0040-1951(91)90446-Y

Quesada, C., P. Fonseca, J. Munhá, J. T. Oliveira, and A. Ribeiro (1994), The Beja-Acebuches Ophiolite (southern Iberia Variscan fold belt): Geological characterization and geodynamic significance, $\mathrm{Bol}$. Geol. Min., 105, 3-49.

Ribeiro, A, et al. (2007), Geodynamic evolution of the SW Europe Variscides, Tectonics, 26, TC6009, doi:10.1029/2006TC002058

Robardet, M. (2003), The Armorica "microplate": Fact or fiction? Critical review of the concept and contradictory palaeobiogeographical data, Palaeogeogr Palaeoclimatol. Palaeoecol., 195, 125-148, doi:10.1016/S0031-0182(03)00305-5.

Rubatto, D., and D. Gebauer (2000), Use of cathodoluminescence for $\mathrm{U}-\mathrm{Pb}$ zircon dating by ion microprobe: Some examples from the Western Alps, in Cathodoluminescence in Geosciences, edited by M. Pagel et al., pp. 373-400, Springer, New York. Sáez, R., E. Pascual, M. Toscano, and G. R. Almodóvar (1999), The Iberian type of volcano-sedimentary massive sulfide deposits, Miner. Deposita, 34 , 549-570, doi:10.1007/s001260050220.
Sánchez Martínez, S., R. Arenas, F. Díaz García, J. R. Martínez Catalán, J. Gómez-Barreiro, and J. A. Pearce (2007), Careón ophiolite, NW Spain: Suprasubduction zone setting for the youngest Rheic Ocean floor, Geology, 35, 53-56, doi:10.1130/ G23024A.1.

Schermerhorn, J. L. G. (1971), An outline stratigraphy of the Pyrite Belt, Bol. Geol. Min., 82, 239-268.

Simancas, J. F., D. J. Martínez Poyatos, I. Expósito, A. Azor, and F. González Lodeiro (2001), The structure of a major suture zone in the SW Iberian Massif: The Ossa-Morena/Central Iberian contact, Tectonophysics, 332, 295-308, doi:10.1016/S0040 1951(00)00262-6.

Simancas, J. F., et al. (2003), Crustal structure of the transpressional Variscan orogen of SW Iberia: SW Iberia deep seismic reflection profile (IBERSEIS), Tectonics, 22(6), 1062, doi:10.1029/2002TC001479.

Simancas, J. F., A. Tahiri, A. Azor, F. González Lodeiro, D. J. Martínez Poyatos, and H. El Hadi (2005), The tectonic frame of the Variscan-Alleghanian orogen in southern Europe and northern Africa, Tectonophysics, 398, 181-198, doi:10.1016/j.tecto.2005. 02.006

Simancas, J. F. et al. (2006), Transpressional collision tectonics and mantle plume dynamics: The Variscides of southwestern Iberia, in European Lithosphere Dynamics, edited by D. G. Gee and R. A. Stephenson, Mem. Geol. Soc., 32, 345-354.

Tait, J., M. Schätz, V. Bachtadse, and H. Soffel (2000), Palaeomagnetism and Palaeozoic palaeogeography of Gondwana and European terranes, in Orogenic Processes: Quantification and Modelling in the Variscan Belt, edited by W. Franke et al., Geol. Soc. Spec. PubL., 179, 21-34.

A. Azor, F. González Lodeiro, D. Martínez Poyatos, and J. F. Simancas, Departamento de Geodinamica, Universidad de Granada, E-18071 Granada, Spain. (azor@ugr.es; lodeiro@ugr.es; djmp@ugr.es; simancas@ ugr.es)

L. M. Martín Parra and J. Matas, Instituto Geológico y Minero de España, E-28760 Tres Cantos Madrid, Spain. (lm.martin@igme.es; j.matas@igme.es)

D. Rubatto, Research School of Earth Sciences, Australian National University, Canberra 0200 ACT, Australia. (daniela.rubatto@anu.edu.au) 